\title{
Sensitivity to copper in Xanthomonas campestris pv. viticola
}

\author{
Eder Marques, Carlos Hidemi Uesugi \& Marisa A.S. Velloso Ferreira
}

Departamento de Fitopatologia, Universidade de Brasília, 70910-900, Brasília, DF, Brazil

Author for correspondence: Marisa A.S. Velloso Ferreira, e-mail: marisavf@unb.br

\begin{abstract}
Bacterial canker, caused by Xanthomonas campestris pv. viticola, affects grapevines in the irrigated areas of the São Francisco river valley, in the states of Pernambuco and Bahia. Several practices for disease management have been adopted including copper sprays. This is the only available chemical control method and most frequently used in the areas affected by the disease. The objective of this work was to determine the sensitivity to copper of strains of $X$. campestris pv. viticola collected in different locations and over a period of years, from 1998 to 2006. Variation in sensitivity to copper oxychloride and copper sulfate was observed among the 21 strains tested. The minimum inhibitory concentration (MIC) varied from 10 to $60 \mu \mathrm{g} / \mathrm{mL} \mathrm{Cu}^{2+}$, for both compounds. A general increase in copper tolerance over the years was also observed, with the Brazilian strains being more tolerant than the type-strain, collected in 1972 in India. The differences observed in copper sensitivity may lead to the selection and dominance of the more tolerant strains in the bacterial population as copper compounds continue to be used in the region.
\end{abstract}

Keywords: Vitis vinifera, copper tolerance, grapevine bacterial canker.

\section{RESUMO}

Sensibilidade ao cobre em Xanthomonas campestris pv. viticola

O cancro bacteriano, causado por Xanthomonas campestris pv. viticola, afeta o cultivo irrigado de videira no Vale do Submédio São Francisco, nos estados de Pernambuco e Bahia. O manejo da doença tem sido realizado através de um conjunto de práticas que inclui a aplicação de cúpricos. Este tem sido o único método de controle químico disponível e o mais utilizado nas áreas de ocorrência da doença. O objetivo deste estudo foi avaliar a sensibilidade ao cobre de estirpes de $X$. campestris pv. viticola coletadas em diferentes localidades, entre os anos de 1998 a 2006. Detectou-se variabilidade na sensibilidade ao oxicloreto de cobre e ao sulfato de cobre entre as 21 estirpes testadas. A concentração mínima inibitória variou entre 10 e $60 \mu \mathrm{g} / \mathrm{mL} \mathrm{Cu}^{2+}$, para os dois produtos. De forma geral, observouse uma evolução no crescimento da tolerância ao cobre ao longo dos anos, com as estirpes brasileiras apresentando maior tolerância que a estirpe-tipo, coletada em 1972 na Índia. As diferenças observadas em sensibilidade ao cobre entre as estirpes de X. campestris pv. viticola podem levar, com o uso contínuo de compostos cúpricos na região, à seleção e dominância das estirpes mais tolerantes na população bacteriana.

Palavras-chave: Vitis vinifera, tolerância ao cobre, cancro bacteriano da videira.

In Brazil, grape (Vitis vinifera L.) production has significantly increased in the irrigated areas of the São Francisco river valley, in the states of Pernambuco and Bahia. This region is responsible for $32 \%$ of the total table grape production in the country, corresponding to approximately $98 \%$ of Brazilian annual grape export (Valexport, 2005). One of the diseases that affect grapevines in that region is bacterial canker, caused by Xanthomonas campestris pv. viticola (Nayudu) Dye. Disease management relies on several cultural practices aiming at reducing inoculum and pathogen dissemination, use of more resistant varieties and protective chemical control with copper sprays, especially after pruning (Malavolta Jr. et al., 1999; MAPA, 2006). Although there are no registered products for bacterial

Part of the Master Thesis of the first author. Universidade de Brasília, Brasília DF. 2007. canker control in Brazil, the spraying of copper compounds is recommended as a protection method to minimize disease damage and spread (Malavolta Jr. et al., 1999; Lima \& Moreira, 2002).

Copper compounds have been widely used for management of bacterial diseases of vegetable and fruit crops. These fungicides are capable of inhibiting or delaying bacterial multiplication (Marco \& Stall, 1983; Romeiro, 1995). However, the efficacy of copper sprays in control of plant bacterial diseases has been variable and is often associated with the occurrence of copper tolerant strains (Marco \& Stall, 1983; Cooksey, 1990). Resistance to copper was not detected in plant pathogenic bacteria until the 1980 s, probably because the presence of copper-resistant strains in the field did not always lead to failure of control with copper sprays (Cooksey, 1990). Since then, several studies have focused on characterizing strain sensitivity and the genetic mechanisms of copper resistance in plant- 
pathogenic bacteria (Cooksey, 1990; Silver \& Phung, 1996; Voloudakis et al., 2005; Teixeira et al., 2008).

Copper resistance has been detected and characterized in Xanthomonas and Pseudomonas. Resistance is widespread in X. campestris pv. vesicatoria (Doidge 1920) Dye, causal agent of bacterial spot of pepper and tomato, in several geographical regions, but it was first reported in Florida (Marco \& Stall,1983), where copper was not effective for disease control. In Brazil, studies have also shown low efficacy of copper compounds to control bacterial spot of sweet pepper (Carmo et al., 2001; Aguiar et al., 2003). Copper-resistant strains have also been described in Pseudomonas syringae pv. tomato (Okabe 1933) Young et al. causing tomato bacterial speck, since copper hydroxide sprays did not reduce disease severity (Cooksey, 1990).

In India, several copper based-compounds and antibiotics were screened for grapevine bacterial canker control, but none of these compounds showed a significant reduction in disease severity (Chand et al., 1991). During a four-year trial conducted in a nursery, grape plants with variable levels of infection were monitored with applications of several copper compounds and antibiotics. At the end of the experiment, the pathogen had acquired resistance to both copper and antibiotics. Tolerant strains were viable after exposure to $600-1800 \mu \mathrm{g} / \mathrm{mL} \mathrm{Cu}^{2+}$ (Chand et al., 1994).
In Brazil, several attempts have been made to determine effectiveness of bactericides for bacterial canker control (Nascimento \& Silva, 1999; Lima \& Mashima, 2000). A mixture of gentamycin sulfate and copper oxychloride was the most effective for inhibiting pathogen growth when compared to other compounds; however, the use of copper sulfate or copper solution to treat propagative plant material with low levels of infection was ineffective (Silva et al., 2000). Tolerance to copper sulfate in five Brazilian strains of $X$. campestris pv. viticola varied from 50 to $300 \mu \mathrm{g} / \mathrm{mL} \mathrm{Cu}^{2+}$. The most sensitive strain was unable to grow after 1-hour exposure to concentrations higher than $50 \mu \mathrm{g} / \mathrm{mL} \mathrm{Cu}^{2+}$ (Araújo 2001; Araújo et al., 2003).

Considering the possibility of reduced sensitivity to copper compounds leading to the prevalence of tolerant strains in the Brazilian populations of this pathogen, the objective of this work was to determine sensitivity to copper of $X$. campestris pv. viticola strains collected in different locations and over a period of years, from 1998 to 2006. This information could contribute to better assess the effectiveness of the control practices based on copper spraying currently adopted in the producing areas.

A total of 21 strains were selected for in vitro studies of copper sensitivity (Table 1). Eighteen strains were obtained from diseased plants collected in Pernambuco

TABLE 1 - Origin and sensitivity to copper of Xanthomonas campestris pv.viticola strains used in this study

\begin{tabular}{|c|c|c|c|c|}
\hline Strain & Host cultivar & Location and year & $\mathrm{CuSO}_{4}$ & $\mathrm{Cu}_{2}\left(\mathrm{Cl}(\mathrm{OH})_{3}\right)$ \\
\hline NCPPB 2475 & Anab-e-Shahi & India, 1972 & $10^{\mathrm{a}}$ & $10^{\mathrm{a}}$ \\
\hline IBSBF 1369 & Red Globe & Petrolina-PE, 1998 & 40 & 60 \\
\hline IBSBF 1385 & Itália & Teresina - PI, 1998 & 40 & 30 \\
\hline UnB 1183 & Red Globe & Area 1, Petrolina- PE, 1998 & 40 & 20 \\
\hline UnB 1190 & Red Globe & Area 2, Petrolina-PE, 1998 & 40 & 30 \\
\hline UnB 1204 & Red Globe & Area 3, Juazeiro-BA, 1999 & 30 & 30 \\
\hline UnB 1205 & Itália & Area 4, Sobradinho-BA, 2000 & 20 & 30 \\
\hline UnB 1216 & Red Globe & Area 5, Petrolina-PE, 2000 & 30 & 40 \\
\hline UnB 1212 & Itália & Area 2, Petrolina-PE, 2001 & 40 & 30 \\
\hline UnB 1222 & Perlette & Area 5, Petrolina-PE, 2001 & 30 & 30 \\
\hline UnB 1292 & Red Globe & Area 6, Juazeiro-BA, 2003 & 50 & 50 \\
\hline UnB 1293 & Superior $\mathrm{x}$ IAC 766 & Area 1, Petrolina-PE, 2003 & 20 & 30 \\
\hline UnB 1294 & Thompson x Paulsen & Area 7, Petrolina- PE, 2003 & 40 & 30 \\
\hline UnB 1295 & Festival & Area 5, Petrolina- PE, 2004 & 30 & 20 \\
\hline UnB 1298 & Itália & Area 5, Petrolina-PE, 2004 & 50 & 30 \\
\hline UnB 1299 & Thompson & Area 8, Petrolina-PE, 2004 & 60 & 40 \\
\hline UnB 1301 & Thompson & Petrolina-PE, 2004 & 50 & 40 \\
\hline UnB 1310 & Festival & Area 9, Petrolina-PE, 2005 & 40 & 50 \\
\hline UnB 1314 & Red Globe & Area 7, Petrolina-PE, 2005 & 40 & 60 \\
\hline UnB 1316 & Red Globe & Area 10, Juazeiro-BA, 2005 & 40 & 60 \\
\hline UnB 1318 & BRS - Morena & Petrolina - PE, 2006 & 50 & 40 \\
\hline
\end{tabular}

${ }^{\mathrm{a}}$ Minimum inhibitory concentration $\left(\mu \mathrm{g} / \mathrm{mL} \mathrm{Cu}^{2+}\right)$ on MMCC (medium minimal complexing copper) 
and Bahia and were identified through biochemical and molecular tests according to Lima et al. (1999) and Trindade et al. (2007), respectively. Two strains were obtained from Instituto Biológico (IBSBF 1385 and 1369) and the type strain (NCPPB 2475) from India was obtained from the National Collection of Plant Pathogenic Bacteria, Central Science Laboratory (Sand Hutton, York, UK). The strains were selected to represent different locations and years of isolation, from 1998 to 2006.

Two copper sensitivity assays were performed. In the first one the MMCC (medium minimal complexing copper) medium was used due to its low ability to complex copper ions (Pohronezny et al., 1992). As sources of copper ions, solutions of copper sulfate $\left(\mathrm{CuSO}_{4}\right)$ and copper oxychloride $\left(\mathrm{Cu}_{2} \mathrm{Cl}(\mathrm{OH})_{3}\right)$ were used. The stock solutions were prepared at a concentration of $2 \times 10^{4} \mu \mathrm{g} / \mathrm{mL}$ and aseptically added to the medium for final concentrations of: $0,10,20,30,40$, 50 and $60 \mu \mathrm{g} / \mathrm{mL} \mathrm{Cu}^{2+}$. Bacterial cultures were recovered from stock cultures maintained in $30 \%$ glycerol at $-80{ }^{\circ} \mathrm{C}$ and transferred to 523 medium (Kado \& Heskett, 1970). After $72 \mathrm{~h}$, bacterial cell suspensions were prepared in sterile distilled water and adjusted to $2.5 \times 10^{8} \mathrm{cfu} / \mathrm{mL}$, using a digital spectrophotometer UV-1203 (Shimazu Corporation) at $550 \mathrm{~nm}$ wave length and 0.575 absorbance. The suspensions were diluted to $10^{-5}(1: 100,000)$, and $50 \mu \mathrm{L}$ were streaked on the copper-containing medium (MMCC) at the desired concentrations. The plates were kept at $28^{\circ} \mathrm{C}$ and the experiment was performed with three replicates for each strain/concentration combination. Plates without added copper were included as controls. After $72 \mathrm{~h}$, the number of colonies on each plate was counted and expressed as cfu/ $\mathrm{mL}$ considering the average of three replicates.

To determine levels of copper sensitivity, a second experiment was conducted according to the method described by Marco \& Stall (1983), which was previously used to evaluate copper tolerance of five strains of $X$. campestris pv. viticola (Araújo, 2001). Copper sulfate was used to prepare copper solutions at the following final concentrations: $0,50,100,150,200,250,300,350$ and 400 $\mu \mathrm{g} / \mathrm{mL} \mathrm{Cu}^{2+}$. The bacterial suspensions were prepared as described above; $50 \mu \mathrm{L}$ of each suspension was added to $1 \mathrm{~mL}$ of copper solutions at each different concentration. After $1 \mathrm{~h}$ exposure, $100 \mu \mathrm{L}$-aliquots were transferred to nutrient-agar medium (NA), with no added copper. Strain sensitivity was evaluated after $72 \mathrm{~h}$ of incubation at $28^{\circ} \mathrm{C}$, based on the presence or absence of bacterial growth.

Sensitivity of $X$. campestris pv. viticola strains to copper was determined through colony counts on MMCC amended with increasing concentrations of copper. For all treatments with both products (copper sulfate and oxychloride), there was a decrease in the number of bacterial colonies with the increase in copper concentration, compared to the control. The MIC value was defined as the lowest concentration in which bacterial growth was totally inhibited. The results showed variation among $X$. campestris pv. viticola strains in their response to copper (Table 1) and a general tendency of increasing tolerance over the years, from 1998 to 2006 (Figure 1).

The MIC value in the treatments with copper sulfate varied from 10 to $60 \mu \mathrm{g} / \mathrm{mL}$ (Table 1) and the type strain NCPPB 2475, from India, was the only highly sensitive strain, with no growth at the lowest concentration tested. Brazilian strains were inhibited at concentrations between 20 and $60 \mu \mathrm{g} / \mathrm{mL} \mathrm{Cu}^{2+}$. One strain, UnB 1299, had the highest MIC value, and was able to grow at $50 \mu \mathrm{g} / \mathrm{mL}$ $\mathrm{Cu}^{2+}$, but completely inhibited at $60 \mu \mathrm{g} / \mathrm{mL} \mathrm{Cu}^{2+}$. The MIC value in the treatments with copper oxychloride also varied from 10 to $60 \mu \mathrm{g} / \mathrm{mL}$ (Table 1) and the type strain NCPPB

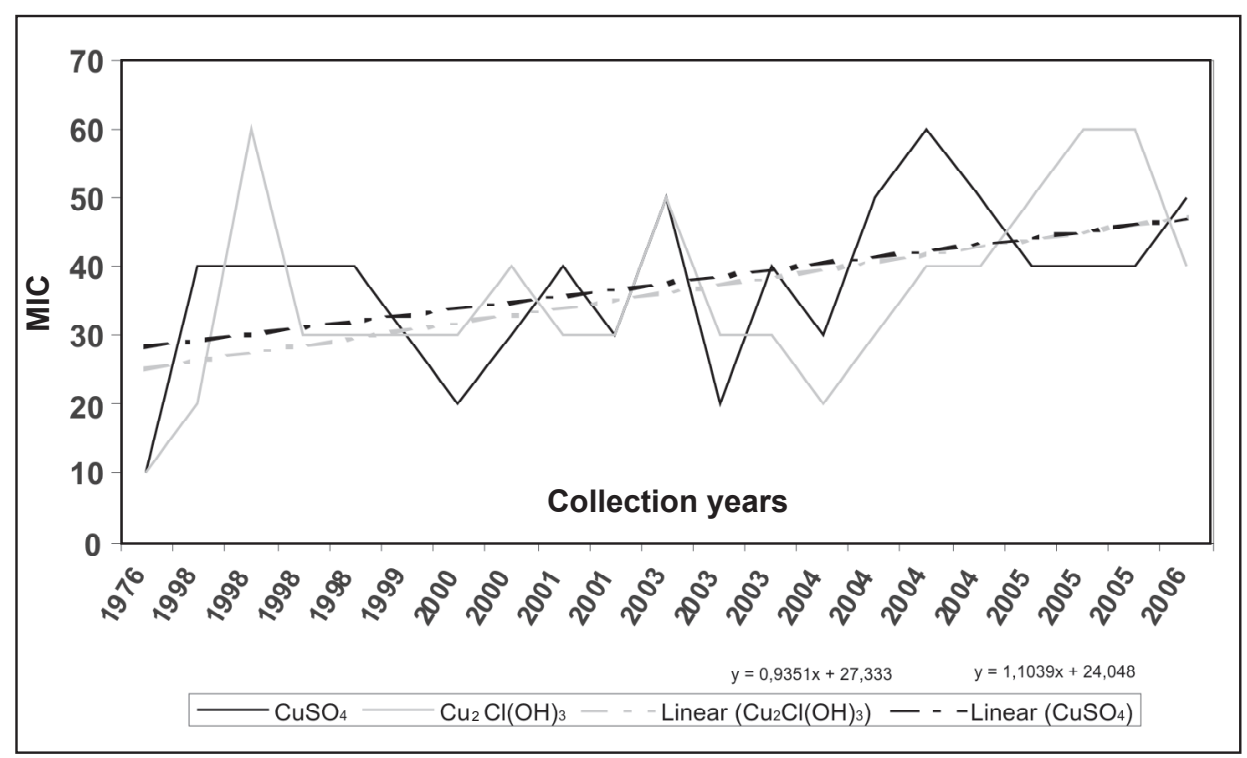

FIGURE 1 - Evolution of copper tolerance in Xanthomonas campestris pv. viticola strains, collected from 1998 to 2006, expressed as the minimal inhibitory concentration (MIC) of copper $(\mu \mathrm{g} / \mathrm{mL})$ on $\mathrm{MMCC}$ (medium minimal complexing copper). 
2475 was, again, the only highly sensitive strain, with no growth at the lowest copper concentration tested $(10 \mu \mathrm{g} /$ $\mathrm{mL})$. Almost half of the strains were inhibited at $30 \mu \mathrm{g} / \mathrm{mL}$, but three strains IBSBF 1369, UnB 1314 and 1316 showed MIC values of $60 \mu \mathrm{g} / \mathrm{mL}$.

Regarding their geographical distribution (Table 1) strains collected in the same area differed in sensitivity to copper in some cases. In Pernambuco, area 2, tolerance was uniform among the two strains collected in 1998 and 2001; in areas 1, 5 and 7, however, tolerance varied among collection years and between the two copper compounds tested. Generally, higher MIC values were observed in strains collected after 2003. For instance, strains with MIC of $50 \mu \mathrm{g} / \mathrm{mL}$ of copper sulfate or higher were collected in 2003, 2004 and 2006 (Table 1).

Seven strains, representing a range in copper sensitivity, were tested using the method described by Marco \& Stall (1983) which employs nutrient-agar medium and the bacterial suspension exposed directly to copper solutions. Copper tolerance varied from 0 to $350 \mu \mathrm{g} / \mathrm{mL}$ (Table 2). Sensitivity of the type strain NCPPB 2475 was confirmed, but strains IBSBF 1385, UnB 1298 and UnB 1301 were also sensitive, being completely inhibited in the lowest concentration tested $(50 \mu \mathrm{g} / \mathrm{mL})$. Strain UnB 1292 showed tolerance up to $200 \mu \mathrm{g} / \mathrm{mL}, \mathrm{UnB} 1299$ up to $250 \mu \mathrm{g} /$ $\mathrm{mL}$, and the most tolerant strain, UnB 1318, collected in 2006, was able to grow after being exposed to $350 \mu \mathrm{g} / \mathrm{mL} \mathrm{Cu}^{2+}$.

The results of the present study showed that Brazilian strains of $X$. campestris pv. viticola differ in their sensitivity to copper sulfate and copper oxychloride, and that more tolerant strains occur naturally in vineyards in Pernambuco and Bahia states. Araújo (2001) examined five strains from Petrolina, PE, but in the present study, a larger number of strains from Pernambuco were included, along with strains collected in Bahia, Piauí and the type strain, from India. The occurrence of more tolerant strains of $X$. campestris $\mathrm{pv}$. viticola may be explained by their introduction associated with propagative material from India, which occurred probably before 1998 when the disease was first detected in Brazil. In 1994, Chand et al. had already detected tolerant strains in India. The continuous use of copper compounds as one of the measures adopted to prevent disease dissemination may have led to the selection of these more tolerant strains (Araújo, 2001).

The variability in tolerance reported here among and within states and areas suggests that tolerant strains already established in the vineyards were then disseminated through propagative plant material to different areas, contributing to the dissemination and maintenance of these populations with the continuous use of copper compounds. Another factor that could be also associated with this process is horizontal gene transfer through conjugation (Cooksey, 1990). It is known that copper-resistant genes are plasmidborne but can also be present in the bacterial chromosome (Basim et al., 2005).

The exclusive use of copper compounds may not be effective as a control measure for $X$. campestris $\mathrm{pv}$. viticola (Araújo, 2001). The gradual increase in tolerance over the years reported here has also been observed in other important plant pathogenic bacteria. Decreased coppersensitivity of strains of $X$. campestris pv. vesicatoria has been reported in Florida, USA, for many years (Marco \& Stall, 1983) and also in Brazil (Carmo et al., 2001; Aguiar et al., 2003; Quezado-Duval et al., 2003). The same has been reported for $P$. syringae pv. tomato in California, USA (Cooksey, 1990) and in Brazil (Silva \& Lopes, 1995). In several cases, cupric and cuprorganic compounds were proven ineffective to control these pathogens, when applied alone. Higher efficiency has been reported when copper is combined with a copper-chelating carbamate fungicide, such as mancozeb. Moreover, in many cases, a reduction in the efficacy to control bacterial diseases has led to an increase in the dosage and frequency of copper applications (Carzola et al., 2002).

In vitro tests are usually performed to determine tolerance to bactericides; however, the results are greatly

TABLE 2 - Copper tolerance of Xanthomonas campestris pv. viticola strains, defined as the presence of bacterial colonies on NA medium after exposure of bacterial cells to copper solutions in various concentrations

\begin{tabular}{|c|c|c|c|}
\hline Strain & Collection year & Origin & Tolerance $\left(\mu \mathrm{g} \mathrm{Cu}{ }^{2+\mid} \mathrm{mL}\right)^{\mathrm{a}, \mathrm{b}}$ \\
\hline NCPPB 2475 & 1972 & India & 0 \\
\hline IBSBF 1385 & 1998 & Teresina - PI & 0 \\
\hline UnB 1292 & 2003 & Juazeiro - BA & 200 \\
\hline UnB 1298 & 2004 & Petrolina - PE & 0 \\
\hline UnB 1299 & 2004 & Petrolina - PE & 250 \\
\hline UnB 1301 & 2004 & Petrolina - PE & 0 \\
\hline UnB 1318 & 2006 & Petrolina - PE & 350 \\
\hline
\end{tabular}

${ }^{\mathrm{a}}$ Copper sulfate

${ }^{b}$ Maximum concentration that supported bacterial growth 


\section{E. Marques et al.}

dependent on the method and the culture medium used. Copper ions bind to many organic substrates in media and on plant surfaces (Cooksey, 1990); thus, several media are known to chelate copper ions, and make them unavailable to inhibit bacterial growth. Tolerance in P. syringae pv. tomato strains from processing tomato was assessed using four different culture media: King's B, NA, 523 and MMCC. Differences in resistance ranged from 250 to $1800 \mathrm{ppm}$ and depended greatly on the culture medium used (Silva \& Lopes 1995). The same was observed by Rezende (2006), when comparing growth of Erwinia psidii on 523 and MMCC amended with copper.

In the present study, the levels of tolerance, expressed as MIC values, for $X$. campestris pv. viticola ranged from 10 to $60 \mu \mathrm{g} / \mathrm{mL} \mathrm{Cu}^{2+}$, when copper ions were added to the medium. Using the same method, E. psidii strains showed growth of up to $30 \mu \mathrm{g} / \mathrm{mL} \mathrm{Cu}^{2+}$ for $\mathrm{CuSO}_{4}$ and up to 50 $\mu \mathrm{g} / \mathrm{mL}$ for copper oxychloride. The second method used for $X$. campestris pv. viticola employs free copper solutions in direct contact with bacterial cells. This may activate resistance genes present in some strains, and through different mechanisms of reduced uptake or detoxification, allow their growth on higher concentrations (200-350 $\mu \mathrm{g} / \mathrm{mL}$ ) of the metal. The structure of the copper-tolerant populations of $X$. campestris pv. viticola could change over time, so a more extensive sampling of strains should be considered in future studies. It should also be of interest to investigate the genetic mechanisms of tolerance in this pathogen.

\section{ACKNOWLEDGEMENTS}

The authors acknowledge the financial support and scholarship granted to Eder Marques by the Conselho Nacional de Desenvolvimento Científico e Tecnológico - $\mathrm{CNPq}$ and wish to thank Daniela Biaggioni Lopes and Mirtes Freitas Lima (Embrapa Semi-Árido) and Loiselene Trindade (Universidade de Brasília) for their collaboration during this project.

\section{REFERENCES}

Aguiar LA, Kimura O, Castilho AMC, Castilho KSC, Ribeiro RLD, Akiba F, Carmo MGF (2003) Efeito de formulações cúpricas e cuprorgânicas na severidade da mancha-bacteriana e na população de Xanthomonas campestris pv. vesicatoria em pimentão. Horticultura Brasileira 21:44-50.

Araújo JSP (2001) Perfil epidemiológico e subsídios para controle de Xanthomonas campestris pv. viticola (Nayudu) Dye agente do cancro bacteriano da videira (Vitis vinifera L.) no Brasil. Tese de Doutorado. Universidade Federal do Rio de Janeiro. Rio de Janeiro RJ.

Araújo JSP, Oliveira BC, Gonçalves KS, Castilho AMC, Ribeiro RLD, Robbs CF (2003) Resistência ao cobre em estirpes brasileiras de Xanthomonas campestris pv. viticola. Fitopatologia Brasileira 28 (Supl):339-340.

Basin H, Minsavage GV, Stall RE, Wang JF, Shanker S, Jones JB (2005) Characterization of a unique chromosomal copper resistance gene cluster from Xanthomonas campestris pv. vesicatoria. Applied and Environmental Microbiology 71:82848291.

Carmo MGF, Macagnan D, Carvalho AO (2001) Progresso da mancha-bacteriana do pimentão a partir de diferentes níveis iniciais de inóculo e do emprego ou não do controle com oxicloreto de cobre. Horticultura Brasileira 19:342-347.

Carzola FM, Arrebola E, Sesma A, Codina JC, Murillo J, Vicente A (2002) Copper resistance in Pseudomonas syringae strains isolated from mango is encoded mainly by plasmids. Phytopathology 92:909-916.

Chand R, Patil PB, Kishum R (1991) Efficacy of different chemicals against grapevine bacterial canker disease. Indian Journal of Plant Protection 20:108-110.

Chand R, Singh PN, Singh D, Singh R (1994) Copper and streptomycin resistance in Xanthomonas campestris pv. viticola. Zeitschrift fur Pflanzenkrankheiten und Pflanzenschutz 101:487491.

Cooksey DA (1990) Genetics of bactericide resistance in plant pathogenic bacteria. Annual Review of Phytopathology 28:201219.

Kado CI, Heskett MG (1970) Selective media for isolation of Agrobacterium, Corynebacterium, Erwinia, Pseudomonas and Xanthomonas. Phytopathology 60:969-976.

Lima MF, Mashima C (2000) Tratamento químico e térmico de bacelos de videira infectados com Xanthomonas campestris pv. viticola. Fitopatologia Brasileira 25 (Supl):324.

Lima MF, Moreira WA (2002) Uva de Mesa. Fitossanidade. Doenças causadas por bactérias. Embrapa Informação Tecnológica. Séries Frutas do Brasil no 14.

Lima M.F, Ferreira MASV, Moreira WA, Dianese JC (1999). Bacterial canker of grapevine in Brazil. Fitopatologia Brasileira 24:440-443.

Malavolta Jr VA, Almeida IMG, Sugimori MH, Ribeiro IJA, Neto Jr EJP, Nogueira EMC (1999) Ocorrência de Xanthomonas campestris pv. viticola em videira no Brasil. Summa Phytopathologica 25:262-264.

MAPA (2006). Instrução Normativa no 09/ 2006. http:// extranetagriculturagovbr/sislegis-consulta/consultarLegislacaodo ?operacao=visualizar\&id $=16772$

Marco GM, Stall RE (1983) Control of bacterial spot of pepper initiated by strains of Xanthomonas campestris pv. vesicatoria that differ in sensitivity to copper. Plant Disease 67:779-781.

Nascimento ARP, Silva ZE (1999) Efeito de agroquímicos sobre a bactéria do cancro da videira. Fitopatologia Brasileira 24 (Supl):252.

Pohronezny K, Sommerfeld M, Raid RN (1992) Streptomycin resistance and copper tolerance among strains of Pseudomonas cichorii in commercial celery seedbeds. Phytopathology 82:1118. Abstract

Quezado-Duval AM, Gazzoto-Filho A, Leite Jr RP, Camargo LEA (2003) Sensibilidade a cobre, estreptomicina e oxitetraciclina em 
Xanthomonas spp. associadas à mancha-bacteriana do tomate para processamento industrial. Horticultura Brasileira 21:670-675.

Rezende AMFA (2006) Estudos sobre a resistência genética e produtos químicos no controle da bacteriose da goiabeira (Psidium guajava) causada por Erwinia psidii. Dissertação de Mestrado. Brasília DF. Universidade de Brasília.

Romeiro RS (1995) Bactérias Fitopatogênicas. Viçosa. Universidade Federal de Viçosa. Imprensa Universitária.

Silva VL, Lopes CA (1995) Isolados de Pseudomonas syringae pv. tomato resistentes a cobre em tomateiros pulverizados com fungicidas cúpricos. Fitopatologia Brasileira 20:85-89.

Silva VAV, Aguiar IF, Castro GSS, Nascimento ARP, Paz CD (2000) Ação in vitro de produtos químicos em relação a Xanthomonas campestris pv. viticola. Fitopatologia Brasileira 25 (Supl):331.
Silver S, Phung LT (1996) Bacterial heavy metal resistance: new surprises. Annual Review of Microbiology 50:753-789.

Teixeira EC, Oliveira JCF, Novo MTM, Bertolini MC (2008) The copper resistance operon cop $A B$ from Xanthomonas axonopodis pathovar citri: gene inactivation results in copper sensitivity. Microbiology 154:402-412.

Trindade LC, Marques E, Lopes DB, Ferreira MASV (2007) Development of a molecular method for detection and identification of Xanthomonas campestris pv. viticola. Summa Phytopathologica 33:16-23.

Valexport (2005) Há 17 anos unindo forças para o desenvolvimento do Vale do São Francisco e da fruticultura brasileira. Petrolina PE.

Voloudakis AE, Reignier TM, Cooksey DA (2005) Regulation of resistance to copper in Xanthomonas axonopodis pv. vesicatoria. Applied and Environmental Microbiology 71:782-789.

TPP 9019 - Received 10 February 2009 - Accepted 19 November 2009 Section Editors: Reginaldo S. Romeiro, Valmir Duarte 